\title{
Exploring the molecular mechanisms of parasite-host interactions with a view towards new therapeutics and vaccines
}

\section{Megan Cross ${ }^{1, \#}$}

Emma Klepzigi,\#

Madeleine Dallaston ${ }^{1, \#}$

Neil D. Young ${ }^{2}$

Ulla-Maja Bailey ${ }^{1}$

Lyndel Mason ${ }^{1}$

Malcolm K. Jones ${ }^{3}$

Robin B. Gasser ${ }^{2}$

Andreas Hofmann ${ }^{1,2,4, \bowtie}$

${ }^{1}$ Structural Chemistry Program, Eskitis Institute, Griffith University, Nathan, Queensland, Australia

${ }^{2}$ Faculty of Veterinary and Agricultural Sciences, The University of Melbourne, Parkville, Victoria, Australia

${ }^{3}$ School of Veterinary Sciences, The University of Queensland, Gatton, Queensland, Australia ${ }^{4}$ Queensland Tropical Health Alliance, Smithfield, Queensland, Australia

Queensland Tropical Health Alliance, Smithfield, Queensland 4878, Australia; e-mail: a.hofmann@griffith.edu.au

\#These authors contributed equally

Received: February 15, 2016

Accepted: March 3, 2016

Key words: helminths, parasite-host interface, tegument proteins

Acknowledgements: AH would especially like to acknowledge Alex Wlodawer's generosity when working as a postdoctoral researcher in his laboratory, and thanks all past and present members of the Hofmann laboratory for their contributions to the above projects over the years. Research in AH's laboratory is funded by the Australian Research Council, the National Health and Medical Research Council and the Rebecca L. Cooper Medical Research Foundation. MC is recipient of an Equity Trustees scholarship.

\section{ABSTRACT}

Despite the massive disease burden worldwide caused by parasitic nematodes and other infectious pathogens, the molecular basis of many infectious diseases caused by these pathogens has been unduly neglected for a long time. Therefore, accelerated progress towards novel therapeutics, and ultimately control of such infectious diseases, is of crucial importance. Capitalising on the wealth of data becoming available from proteomic and genomic studies, new protein targets at the pathogen-host interface can be identified and subjected to protein-based explorations of the molecular basis of pathogen-host interactions. By combining the use of systems and structural biology methodologies, insights into the structural and molecular mechanisms of these interactions can assist in the development of therapeutics and/or vaccines. This brief review examines two different proteins from the body wall of blood flukes - annexins and the stress-induced phosphoprotein 1 - both of which are presently interesting targets for the development of therapeutics.

\section{INTRODUCTION}

Infectious diseases caused by eukaryotic pathogens are one of the major burdens on human populations world-wide. In the absence of effective preventative approaches and new intervention strategies, the adverse impact caused by many infectious diseases is likely to increase further [1,2], compounded by food and water shortages, economic crises, wars and climate change, particularly in disadvantaged countries. In addition, there is evidence of increasing problems with resistance in pathogens to a wide range of chemotherapeutic agents, compromising the treatment of infectious diseases [3]. The high degree of globalisation, as well as climate change due to global warming contributes to the spread of these diseases and their vectors. Originally confined to tropical areas, parasitic diseases are now extending to higher altitudes in mountain ranges, and to higher latitudes with tempered climates that were previously spared; this spread has already been documented in the USA [4] and Mediterranean regions [5].

Schistosomiasis is a chronic disease of humans that is persistently linked to poverty. As such it is exemplary for the many neglected infectious diseases caused by parasites that often exist as a vicious cycle in endemic populations, in which poverty is a major cause and/or consequence of disease problems. In the case of schistosomiasis, the underlying socio-economic reasons for the spread of the disease often include a lack of sanitation and hygiene measures and ecological management. Health education and changes of traditional behaviour are therefore an integral part of a rigorous program to control these diseases [6]. The burden of disability posed by these human helminths extends beyond the immediate disease symptoms, since effects of chronic infection, such as anaemia and impaired mental and physical fitness also need to be considered [7]. It is estimated that globally some 258 million people required treatment in 2014, and at least double as much live in endemic areas and are therefore at risk [8]. The life cycle of schistosomes includes snails as intermediate hosts, which release the infective larvae (cercariae) that penetrate the skin of the human host and then transform to schistosomula (transformed parasites) and adults. Schistosomula migrate to their final location in the veins. Whereas Schistosoma mansoni and Schistosoma japonicum typically reside in blood vessels surrounding the gut and liver, Schistosoma haematobium locates to venules around the bladder and genital tract. In the resident location, the females deposit eggs in the venules, which are eliminated by the host in faeces or urine, thus completing the life cycle. 
The disease schistosomiasis is principally the consequence of host responses against parasite eggs deposited in the blood vessels. However, control is directed towards killing adult worms or preventing transmission of larvae that establish infection. Since the 1970s, the control of schistosomiasis relies almost exclusively on treating people with the drug praziquantel, which has proven to be a highly effective compound that, so far, is unsurpassed in terms of safety, price and administration route [9]. The detailed mechanism of action of this drug is not clear, but voltage-operated calcium channels have been named as a possible target, and the calcium homeostasis is indeed substantially disturbed after exposure to the compound. At a functional level, the drug causes severe spasms and paralysis in the musculature of the worms, as well as severe morphological distortions which lead to exposure of schistosomal antigens to the host immune system, and ultimately their destruction and clearance from the host [10]. The comparably low cost and oral administration are two major reasons for using this drug in current preventative chemotherapy. The evident shortcoming of this approach is that the drug requires periodic and repeated application, and the high rates of re-infection occurring after mass treatment limit this strategy. Additionally, the exclusive and fairly extensive use of a single drug over decades raises a concern about drug resistance, particularly since the disease is still highly endemic in many countries. Although there have been only a small number of reported cases of decreased sensitivity to praziquantel [9], the requirement for alternative treatments remains an urgent item on the World Health Organization agenda [11,12].

Prophylactic vaccination would be an ideal approach for sustainable control of schistosomiasis, alone or in combination with anthelmintic drugs [13]. Building on the promising results obtained with using irradiated cercariae as a vaccine [14], recombinant antigens obtained from the surface membrane of schistosomes have been tested and resulted in protection in mice, measured by reduced parasite burdens and fecundity [15], indicating that this layer might be the key to understanding parasite-host interactions and effective immunisation against schistosomes [16]. Experimental vaccination with recombinant peptides of two molecules from the surface membrane, TSP2 and Sm29, induced strong protection in experimentally induced schistosomiasis in mice, as measured by reduction in adult worm burdens and egg production [15], but, as yet, neither molecule produces sterilising immunity nor prolonged immunological memory. Two vaccines are currently in development, one based on glutathione S-transferase (named Bilhvax) and the other on a fatty acid-binding protein called Sm14, but unfortunately show slow progress to date. Whereas very little information about Bilhvax has been published so far, the initially promising high level of protection achieved with the Sm14-based vaccine is proving difficult to reproduce [13].

In the quest for finding novel vaccine targets against schistosomiasis and other helminth diseases, we follow a rationale, comprising three criteria; the target protein should:

(i) be expressed in reasonable abundance; (ii) be expressed in a way such as to be recognised by an acquired immune response which requires either a surface-exposed location or secretion across the surface or in anterior regions of the digestive system; and (iii) display key differences in functional domains from related host molecules.

In addition, if the selected target molecules fulfil a fundamental or essential function that ensures the survival of the pathogen, then this warrants the investigation of the target for drugability. In this brief review, we highlight two novel proteins of interest and with potential for vaccine development against schistosomiasis and other helminthic diseases.

\section{THE SCHISTOSOME TEGUMENT}

Schistosomes are metazoan flatworms and have evolved with their mammalian hosts. The parasitic multi-cellular eukaryotes are able to survive for up to 30 years in the host, and therefore have developed mechanisms to evade the host

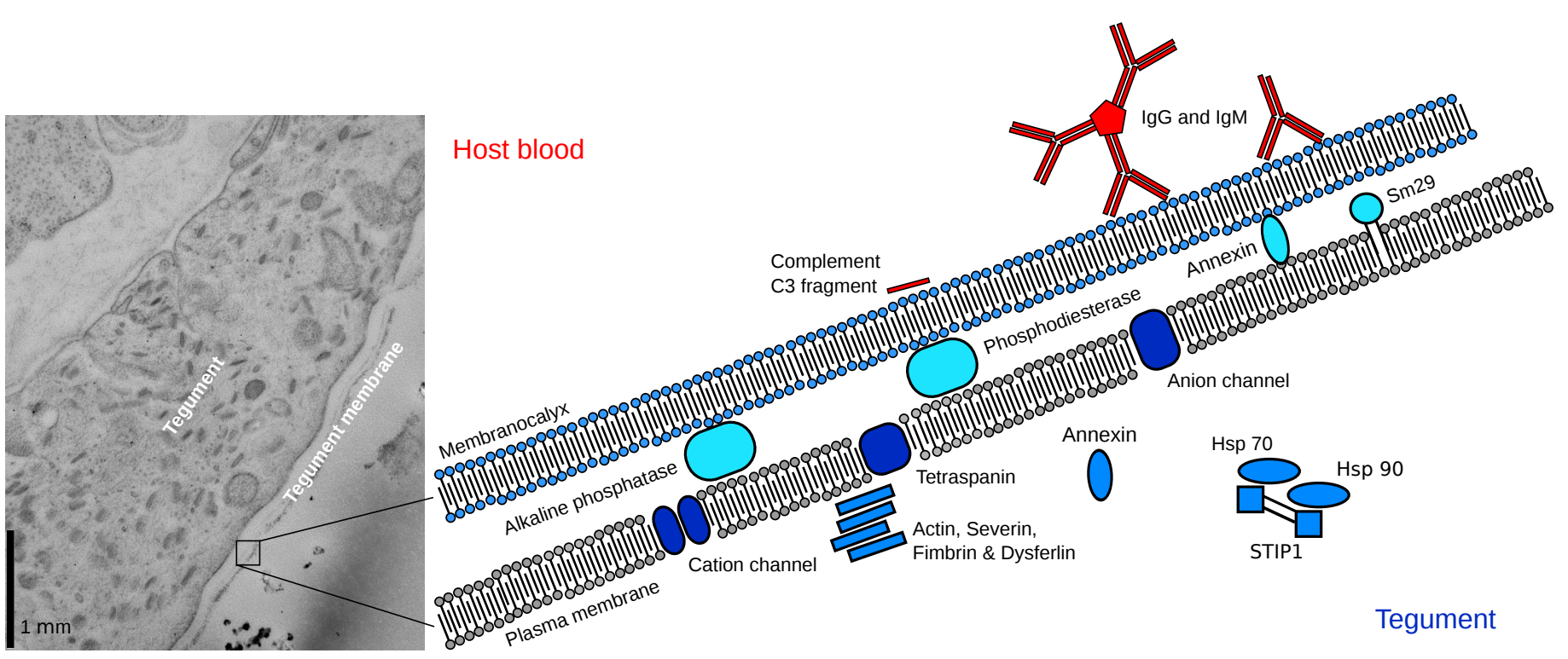

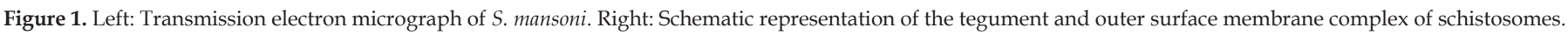




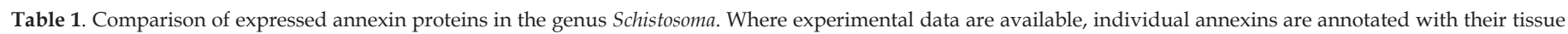
location: $\mathrm{t}$ - tegument, a - apical membrane complex, $\mathrm{g}$ - gut lining, $\mathrm{v}$ - vitelline gland. For a detailed review, see [37].

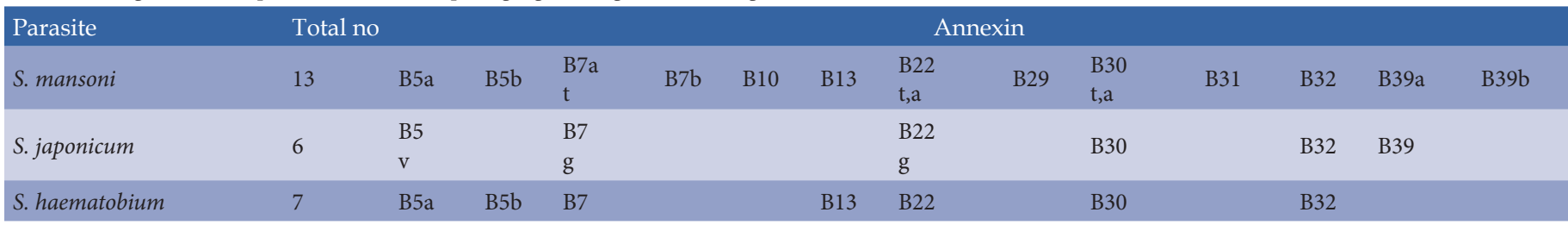

immune system. The external part of the body wall (tegument) of intravascular schistosomes is the predominant region that interfaces with the host animal [17]. The tegument comprises a syncytium (fused giant cells) and interacts with the host by means of a surface membrane overlaid with a schistosome-specific membranocalyx (see Fig. 1), so that the surface membrane has the appearance of a dual bilayer [18]. When the cercariae migrate through the skin of their human hosts, they rapidly remodel their surface membrane [19], refashioning the apical membrane from the single-layered and richly protein- and glycan-ornamented membrane of the cercaria, to the dual membrane complex of parasitic stages [20]. Cercarial transformation is complete within hours and the transformed parasite is masked from host immune attack [21]. This transformation is crucial for parasite survival; if the parasite cannot transform, it is eliminated by the host immune system, primarily within the skin or along the migratory path of the parasite in the bloodstream or the lung [22].

The tegumental proteome mainly consists of proteins involved in molecular trafficking to support the transport of vesicles to outer surface membranes [21] and proteins mediating cytoskeletal functions, in accordance with the observed extensive and dynamic cytoskeletal structures [17]. Additionally, $\sim 25 \%$ of tegument proteins are schistosome-specific and lack any sequence similarity with host proteins [23].

This unique outer-surface structure (tegument) appears to be an adaptation that ensures survival of the parasite in the blood stream and this surface structure is indeed found in all flatworms [24]. The immune evasion mechanisms linked to the tegument comprise at least two different strategies: rapid membrane turnover and proteolytic degradation of host immune defence molecules. Even after the dramatic transformation from the cercaria to the schistosomula stage where the parasite establishes its outer-surface membrane, the mature worms continues to fuse multilamellar bodies from the tegument with the inner bilayer of the tegument membrane and the contents of the multilamellar bodies are distributed onto the outer bilayer [25]. The tegument may also fuse with host immune cells and thereby acquire host antigens, helping to mask the parasite [26].

\section{ANNEXINS}

Annexins are soluble proteins ubiquitous in the eukaryotic kingdom and possess, in addition to an N-terminal region of variable length, a highly conserved fold of four repeats (I-IV) that enables general adapter-like functions at the surface of phospholipid membranes [27].
Members of the annexin family are consistently identified in diverse parasite groups, ranging from protists such as Giardia, to platyhelminths, such as Schistosoma and taeniid cestodes [28]. In Giardia, an intestinal parasite of vertebrates, the annexins (also called a-giardins) appear to stabilise the parasite against membrane breakdown and structural collapse [29]. The annexin a1-giardin is an established vaccine candidate against Giardia [30], and its peculiar calcium-regulated mechanisms have highlighted a fundamental role for this protein in Giardia transformation (excystation) and the accompanying significant structural changes [31].

The presence of annexins in the tegumental proteome of schistosomes suggested a role for this protein in the formation and maintenance of the surface lipid bilayers, possibly anchoring the outer to the inner bilayer [23], or engaging in mechanisms similar to those in their mammalian relatives during plasma/cell membrane repair [32-35]. With the availability of the genomes of several parasitic organisms, including S. japonicum, S. mansoni and S. haematobium, we have been able to conduct a genome-wide survey of annexins in invertebrates (B annexins), which can be organised into six clades [36]. Five annexins (B5, B7, B22, B30 and B32; see Table 1) are conserved among the three schistosome species, and annexins B22 and B30 localise to the apical membrane complex [37].

By using structure-based amino acid sequence alignments, we discovered that many parasite annexins possess a unique structural feature whereby the linker region between repeats II and III is extended when compared with mammalian annexins and predicted to adopt an a-helical structure [28]. While the length of this linker region in annexins is typically $10-15$ amino acid residues, we identified linker peptides extending over 25-38 amino acid residues in many parasitic species, and consistently found that those with more than 25 amino acid residues included a (predicted) a-helical segment absent from any other annexin known at the time.

Experimental proof for this prediction has been obtained with the first crystal structure of any schistosome annexin [38]. The elongated linker region between repeats II and III of annexin B22 from S. mansoni indeed confers a unique surface-exposed structural element onto the parasite protein. The linker segment adopts an a-helical structure which, in annexin B22, embraces the N-terminal domain packed against the concave surface of the protein (see Fig. 2).

Although the quaternary structure of annexin B22 in the schistosomal tegument is unknown, in vitro data sug- 

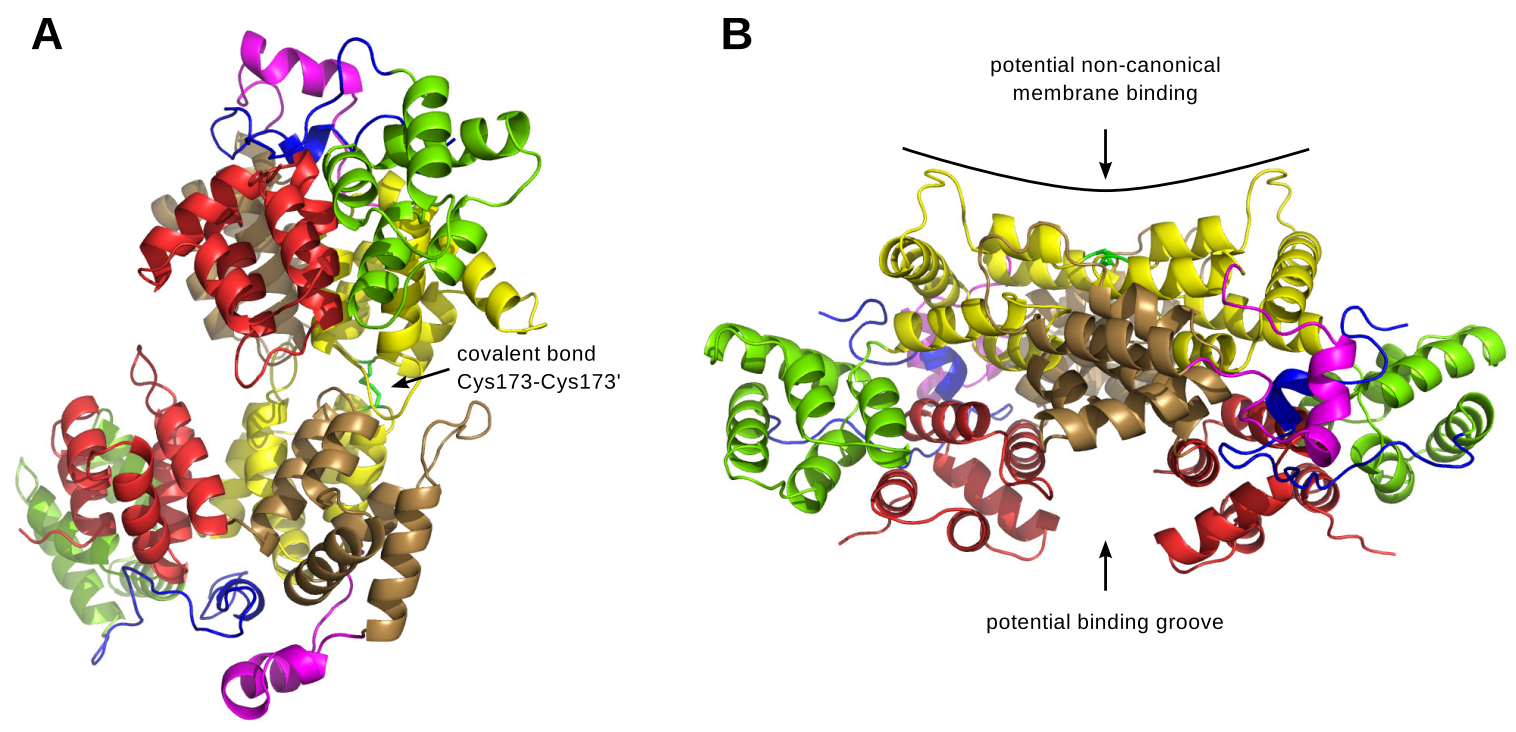

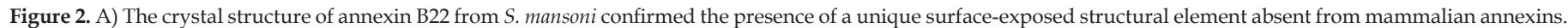

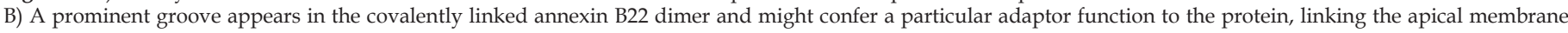

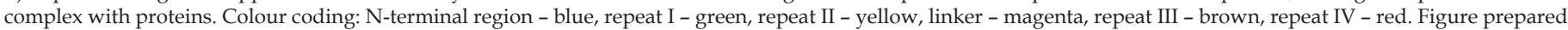
with PyMOL [48].

gest that it may undergo a redox and calcium-mediated dimerisation where an exposed cysteine residue in the IIDE loop plays a pivotal role. The crystal structure of annexin B22 revealed a head-to-head dimer, formed by intimate contacts between the convex sides of repeats II and III (see Fig. 2), thus rendering the convex surfaces of repeats I and IV accessible for potential canonical membrane interactions. The cysteine residues in the IIDE loop of both monomers engage in a disulphide bond. Supported by membrane binding and aggregation assays [38], we have proposed a novel non-canonical membrane binding site provided by this unique annexin dimer which may confer a particular mechanistic role of the conserved annexin B22 in maintenance and turnover of the apical membrane complex. Notably, annexin B22 is conserved also in other parasitic platyhelminthes such as Fasciola and Clonorchis, which also possess tegument structures, thus further supporting the idea of annexin B22 playing a fundamental role in the apical membrane mechanisms.

Preliminary immunobiochemical characterisation of annexin B22 has revealed that serum of mice infected with S. mansoni recognises the recombinant protein with low cross-reactivity to other S. mansoni annexins (unpublished). Future studies need to localise the functional epitope(s) and assert that these induce protective effects.

\section{STRESS-INDUCED PHOSPHOPROTEIN 1 (STIP1)}

In a high throughput cloning and expression study, 200 genes encoding $S$. japonicum tegument proteins were surveyed for immunoreactivity using serum from patients suffering from schistosomiasis japonica [39]. The most immunogenic proteins recognised by sera from multiple patients included inorganic pyrophosphatase, phosphoglycerate kinase and STIP1. STIP1, the tegument protein eliciting the strongest immunogenic response [39], interacts with and regulates the Hsp90 and Hsp70 chaperones
[40], but possesses no chaperone activity itself [41]. Based on structure-function studies of isolated STIP1 domains, it is believed that the co-chaperone STIP1 simultaneously binds to Hsp90 and Hsp70 and mediates the substrate transfer, and inhibits the Hsp90 ATPase activity [42].

Previous studies of this co-chaperone have focused on the homologous human and yeast proteins (also called Sti1, Hop) and revealed that STIP1 is a monomeric protein $[43,44]$ that initially binds Hsp90 and Hsp70:client with different domains. Facilitated by a flexible linker between both domains, the Hsp70:client complex is then brought into spatial vicinity of Hsp90, from which the client is transferred to the Hsp90 binding site [42].

Structurally, these functions are supported by a modular architecture composed of tetratricopeptide repeats (TPRs). These repeats fold into two anti-parallel a-helices (the TPR motif) that are arranged in tandem arrays and often found in protein-protein interaction modules [45]. Human and yeast STIP1 consist of three TPR domains (TPR1, TPR2A and TPR2B with three TPR motifs each), as well as two domains rich in aspartate and proline residues, hence called DP domains [46]. The DP1 domain is located C-terminally of TPR1 and constitutes the N-terminal moiety that is connected by a flexible linker to the C-terminal moiety of the protein (Fig. 3A). The latter moiety comprises the domains TPR2A and TPR2B that are connected by a rigid helical linker that arrests the relative orientation of both of these TPR domains [42]. The DP2 domain forms the most C-terminal part of the protein.

In a survey of protein sequences of select nematodes, we identified eight trematode STIP1 proteins and analysed their structural topologies. Intriguingly, all but the Echinococcus STIP1 proteins comprise of the second moiety of human/yeast STIP1 only (Fig. 3A, B). In this context it is of interest that yeast STIP1 devoid of the N-terminal 
A

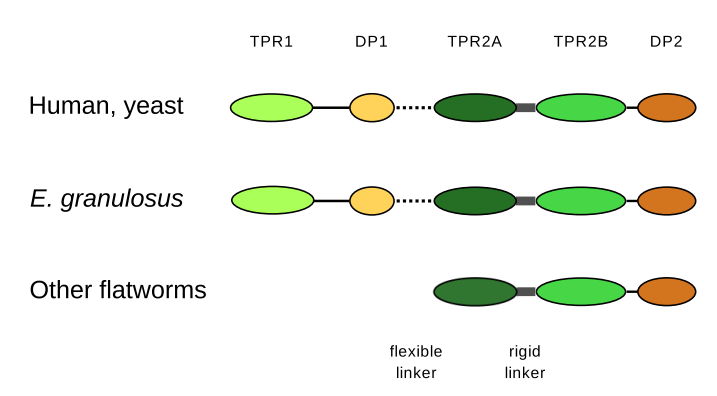

C

C DP2

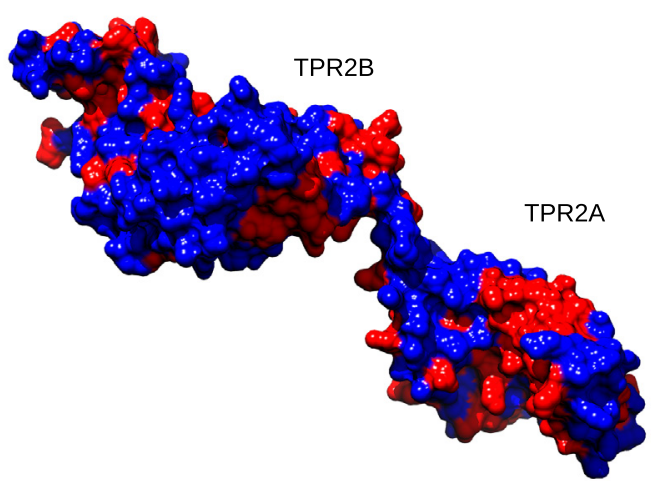

B
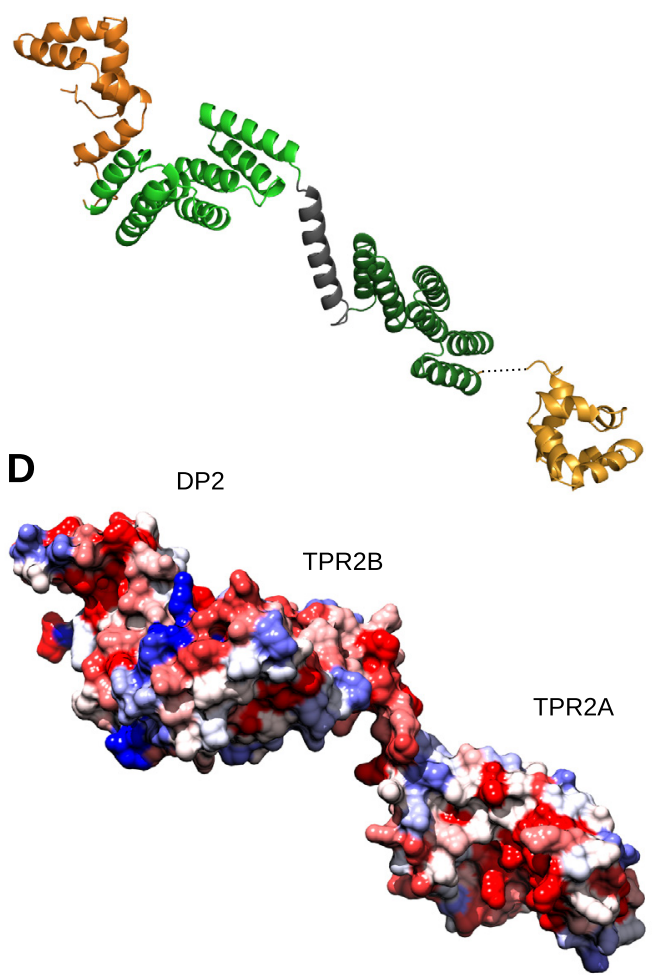

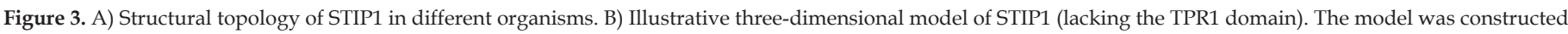

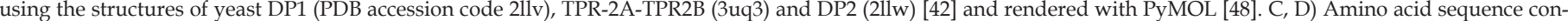

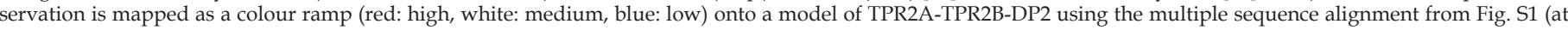

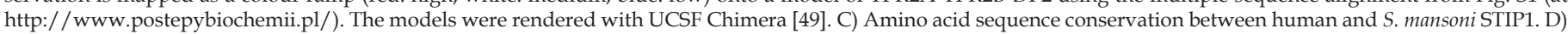
Amino acid sequence conservation among trematode STIP1 sequences.

moiety (TPR1-DP1) exhibited client activation, like the full-length protein, indicating that the N-terminal moiety is dispensable for the activation process and Hsp70 should be able to bind to the TPR2B domain directly, without the need for a transfer facilitated by the STIP1 N-terminal moiety [42].

Unlike the situation with annexins, there is no prominent unique structural element in trematode STIP1 proteins when compared to its mammalian orthologues. However, an assessment of amino acid conservation between trematode and human STIP1 reveals that mainly positions of importance for intramolecular interactions in the TPR domains are conserved between human and trematodes (coloured red in Fig. 3C). In contrast, many positions that are likely to engage in inter-molecular interactions ('surface-exposed') show low conservation between humans and nematodes (coloured blue in Fig. 3C) and thus might serve as antigenic epitopes. Moreover, analysis of the amino acid conservation among parasitic STIP1 homologues reveals several areas of medium to high conservation (coloured white/red in Fig. 3D). From the perspective of developing vaccines, the recognition of STIP1 from more than one pathogen may allow the development of multivalent vaccines.

The strong immunoreactivity of S. japonicum STIP1 [39] raises high hopes for it becoming a promising candidate molecule. Future studies will need to determine the extent of any protective effects and map epitopes on recombinant STIP1.

\section{CONCLUSION}

Despite the substantial existing impact of schistosomes and other parasitic helminths that affect hundreds of millions of people worldwide, these pathogens are rather neglected when it comes to funding for fundamental research and the development of novel therapeutics, vaccines and diagnostics. A recent survey of vaccine experts in R\&D and advocacy ranked helminth vaccines among the top ten targets of highest priority [47].

The socioeconomic consequences resulting from parasitic infections have a major adverse impact on human health, exacerbated by the global food and water shortages. Since most parasites are controlled mainly by chemotherapy, it is imperative to prevent serious problems with drug resistance due to the excessive and often uncontrolled use of such agents. Additionally, the potential increase of these infectious diseases in previously unaffected parts of the world due to the changing climate further emphasises the urgency for novel and innovative solutions.

Parasites are very effective at masking themselves in the host, which presents a major impediment for their effective control. However, there are brief windows of opportunity during their development and migration, particularly early during their invasion of the mammalian host, when immu- 
nogenic proteins are expressed and exposed. It is thus crucial to understand how parasites maintain their structural integrity and survive during host invasion and attack.

By capitalising on the wealth of genomic and transcriptomic sequence data, which are increasingly becoming available for parasitic worms, it is now possible to identify vaccine targets in a systematic fashion. Combined with a structural appraisal of the target proteins, the criteria for an ideal vaccine target can be applied and suitable candidates selected in an informed manner. Annexins and STIP1 are two candidate proteins that we have identified in our ongoing studies by employing this advanced methodology. As briefly discussed in this review, both proteins possess the desired properties of an ideal vaccine target (abundantly expressed, suitable location, key differences to related host molecules); future studies will need to localise their functional epitopes and address their efficiency in eliciting protective effects.

Research of protein structure-function relationships at the parasite-host interface will advance our knowledge of the fundamental molecular mechanisms that help to better understand the molecular basis of infectious diseases. However, equally important will be the translation of these findings to develop novel and improved preventative and therapeutic interventions against parasites.

\section{REFERENCES}

1. Kutz S, Dobson A, Hoberg E (2009) Where are the parasites? Science 326: $1187-1188$

2. Mills JN, Gage KL, Khan AS (2010) Potential influence of climate change on vector-borne and zoonotic diseases: a review and proposed research plan. Environ Health Perspect 118: 1507-1514

3. Barry CE (2011) Lessons from seven decades of antituberculosis drug discovery. Curr Top Med Chem 11: 1216-1225

4. Pascual M, Dobson A, Bouma M (2009) Underestimating malaria risk under variable temperatures. Proc Natl Acad Sci USA 106: 13645-13646

5. Kington T (2007) Climate change brings malaria back to Italy. The Guardian 6 January 2007

6. Evans AC, Stephenson LS (1995) Not by drugs alone: the fight against parasitic helminths. World Health Forum 16: 258-261

7. King CH, Dickman K, Tisch DJ (2005) Reassessment of the cost of chronic helmintic infection: a meta-analysis of disability-related outcomes in endemic schistosomiasis. Lancet 365: 1561-1569

8. World Health Organisation (2016) Schistosomiasis Fact sheet. http:// www.who.int/mediacentre/factsheets/fs115/en/, updated February 2016

9. Cioli D, Pica-Mattoccia L, Basso A, Guidi A (2014) Schistosomiasis control: praziquantel forever? Mol Biochem Parasitol 195: 23-29

10. Pica-Mattoccia L, Orsini T, Basso A, Festucci A, Liberti P, Guidi A, Marcatto-Maggi A-L, Nobre-Santana S, Troiani A-R, Cioli D, Valle C (2008) Schistosoma mansoni: Lack of correlation between praziquantel-induced intra-worm calcium influx and parasite death. Exp Parasitol 119: 332-335

11. Colley DG, Secor WE (2007) A schistosomiasis research agenda. PLoS Negl Trop Dis 1: e32

12. PAHO/WHO (2014) Defining a road map toward verification of elimination of schistosomiasis transmission in Latin America and the Caribbean by 2020 .

13. Loukas A, Tran M, Pearson MS (2007) Schistosome membrane proteins as vaccines. Int J Parasitol 37: 257-263
14. Minard P, Dean DA, Jacobson RH, Vannier WE, Murrell KD (1978) Immunization of mice with cobalt-60 irradiated Schistosoma mansoni cercariae. Am J Trop Med Hyg 27: 76-86

15. Tran M, Pearson M, Bethony J, Smyth D, Jones M, Duke M, Don T, McManus D, Correa-Oliveira R, Loukas A (2006) Tetraspanins on the surface of Schistosoma mansoni are protective antigens against schistosomiasis. Nature Med 12: 835-840

16. Kupferschmidt K (2013) A worm vaccine, coming at a snail's pace. Science 339: 502-503

17. Jones MK, Gobert GN, Zhang L, Sunderland P, McManus DP (2004) The cytoskeleton and motor proteins of human schistosomes and their roles in surface maintenance and host-parasite interactions. Bioessays 26: $752-765$

18. Gobert GN, Stenzel DJ, McManus DP, Jones MK (2003) The ultrastructural architecture of the adult Schistosoma japonicum tegument. Int J Parasitol 33: 1561-1575

19. Jones MK, Lustigman S, Loukas A (2008) Tracking the odysseys of juvenile schistosomes to understand host interactions. PLoS Negl Trop Dis 2: e257

20. Skelly PJ, Wilson AR (2006) Making sense of the schistosome surface. Adv Parasitol 63: 185-284

21. Skelly PJ, Shoemaker CB (2001) The Schistosoma mansoni host-interactive tegument forms from vesicle eruptions of a cyton network. Parasitology $122 \mathrm{Pt}$ 1: 67-73

22. Wilson R, Coulson P (2009) Immune effector mechanisms against schistosomiasis: looking for a chink in the parasite's armour. Trends Parasitol 25: 423-431

23. van Hellemond JJ, Retra K, Brouwers JFHM, van Balkom BWM, Yazdanbaksh M, Shoemaker CB, Tielens AGM (2006) Functions of the tegument of schistosomes: clues from the proteome and lipidome. Int J Parasitol 36: 691-699

24. McLaren DJ, Hockley DJ (1977) Blood flukes have a double outer membrane. Nature 269: 147-149

25. Wilson RA, Barnes PE (1977) The formation and turnover of the membranocalyx on the tegument of Schistosoma mansoni. Parasitology 74: 61-71

26. Caulfield JP, Korman G, Butterworth AE, Hogan M, David JR (1980) The adherence of human neutrophils and eosinophils to schistosomula: evidence for membrane fusion between cells and parasites. J Cell Biol 86: 46-63

27. Benz J, Hofmann A (1997) Annexins - From structure to function. Biol. Chem 378: 177-183

28. Hofmann A, Osman A, Leow CY, Driguez P, McManus DP, Jones MK (2010) Parasite annexins - new molecules with potential for drug and vaccine development. BioEssays 32: 967-976

29. Peattie DA, Alonso RA, Hein A, Caulfield JP (1989) Ultrastructural localization of giardins to the edges of disk microribbons of Giardia lamblia and the nucleotide and deduced protein sequence of alpha giardin. J Cell Biol 109: 2323-2335

30. Jenikova G, Hruz P, Andersson MK, Tejman-Yarden N, Ferreira PCD, Andersen YS, Davids BJ, Gillin FD, Svärd SG, Curtiss R3, et al. (2011) A1-giardin based live heterologous vaccine protects against Giardia lamblia infection in a murine model. Vaccine 29: 9529-9537

31. Weeratunga SK, Osman A, Hu NJ, Wang CK, Mason L, Svärd S, Hope G, Jones MK, Hofmann A (2012) alpha-1 giardin is an annexin with highly unusual calcium-regulated mechanisms. J Mol Biol 423: 169-181

32. Piljic A, Schultz C (2006) Annexin A4 self-association modulates general membrane protein mobility in living cells. Mol Biol Cell 17: 33183328

33. Skrahina T, Piljic A, Schultz C (2008) Heterogeneity and timing of translocation and membrane-mediated assembly of different annexins. Exp Cell Res 314: 1039-1047

34. Bouter A, Gounou C, Bérat R, Tan S, Gallois B, Granier T, d'Estaintot BL, Pöschl E, Brachvogel B, Brisson AR (2011) Annexin-A5 assembled into two-dimensional arrays promotes cell membrane repair. Nat Commun 2: 270 
35. Draeger A, Monastyrskaya K, Babiychuk EB (2011) Plasma membrane repair and cellular damage control: the annexin survival kit. Biochem Pharmacol 81: 703-712

36. Cantacessi C, Seddon JM, Miller TM, Lee CY, Thomas L, Mason L, Willis C, Walker G, Loukas A, Gasser B, et al. (2013) A genome-wide analysis of annexins from parasitic organisms and their vectors. Sci Rep 3: 2893

37. Leow CY, Willis C, Gasser RB, Hofmann A, Jones MK (2015) Structure-function analysis of apical membrane-linked molecules for treatment and control of schistosome parasites of humans: insights from studies into annexins. Br J Pharmacol 172: 1653-1663

38. Leow CY, Willis C, Osman A, Mason L, Simon A, Smith BJ, Gasser RB, Jones MK, Hofmann A (2013) Crystal structure and immunological properties of the first annexin from Schistosoma mansoni - Insights into the structural integrity of the schistosomal tegument. FEBS J 281: 1209-1225

39. Chen J, Zhang T, Ju C, Xu B, Lu Y, Mo X, Chen S, Fan Y, Hu W, Zhou X (2014) An integrated immunoproteomics and bioinformatics approach for the analysis of Schistosoma japonicum tegument proteins. J Proteom 98: 289-299

40. Flom G, Behal RH, Rosen L, Cole DG, Johnson JL (2007) Definition of the minimal fragments of Sti1 required for dimerization, interaction with Hsp70 and Hsp90 and in vivo functions. Biochem J 404: 159-167

41. Bose S, Weikl T, Bügl H, Buchner J (1996) Chaperone function of Hsp90-associated proteins. Science 274: 1715-1717

42. Schmid AB, Lagleder S, Gräwert MA, Röhl A, Hagn F, Wandinger SK, Cox MB, Demmer O, Richter K, Groll M, et al. (2012) The architecture of functional modules in the Hsp90 co-chaperone Sti1/Hop. EMBO J 31: 1506-1517
43. Yi F, Doudevski I, Regan L (2010) HOP is a monomer: investigation of the oligomeric state of the co-chaperone HOP. Protein Sci 19: 19-25

44. Li J, Richter K, Buchner J (2011) Mixed Hsp90-cochaperone complexes are important for the progression of the reaction cycle. Nat Struct Mol Biol 18: 61-66

45. Blatch GL, Lässle M (1999) The tetratricopeptide repeat: a structural motif mediating protein-protein interactions. Bioessays 21: $932-939$

46. Nelson GM, Huffman H, Smith DF (2003) Comparison of the carboxy-terminal DP-repeat region in the co-chaperones Hop and Hip. Cell Stress Chaperones 8: 125-133

47. Cohen J (2016) Unfilled vials. Science 351: 16-19

48. DeLano W (2002) The PyMOL Molecular Graphics System. http:// www.pymol.org

49. Pettersen EF, Goddard TD, Huang CC, Couch GS, Greenblatt DM, Meng EC, Ferrin TE (2004) UCSF Chimera - a visualization system for exploratory research and analysis. J Comput Chem 25: 1605-1612

50. Wang CK, Broder U, Weeratunga SK, Gasser RB, Loukas A, Hofmann A (2012) SBAL: a practical tool to generate and edit structure-based amino acid sequence alignments. Bioinformatics 28: 1026-1027

51. Bryson K, McGuffin LJ, Marsden RL, Ward JJ, Sodhi JS, Jones DT (2005) Protein structure prediction servers at University College London. Nucl Acids Res 33: W36-W38

52. Wang CK, Hofmann A (2015) An integrated Java tool for generating amino acid sequence alignments with mapped secondary structure elements. 3Biotech 5: 87-92

\title{
Badania nad molekularnymi mechanizmami oddziaływań pasożyt-gospodarz w celu opracowania nowych strategii terapeutycznych i szczepionek
}

\author{
Megan Cross ${ }^{1, \#}$, Emma Klepzigi,"\#, Madeleine Dallaston ${ }^{1, \#}$, Neil D. Young'², Ulla-Maja Bailey ${ }^{1}$, \\ Lyndel Mason ${ }^{1}$, Malcolm K. Jones ${ }^{3}$, Robin B. Gasser ${ }^{2}$, Andreas Hofmann ${ }^{1,2,4, \bowtie}$
}

${ }^{1}$ Structural Chemistry Program, Eskitis Institute, Griffith University, Nathan, Queensland 4111, Australia

${ }^{2}$ Faculty of Veterinary and Agricultural Sciences, The University of Melbourne, Parkville, Victoria 3010, Australia

${ }^{3}$ School of Veterinary Sciences, The University of Queensland, Gatton, Queensland 4343, Australia

${ }^{4}$ Queensland Tropical Health Alliance, Smithfield, Queensland 4878, Australia

e-mail: a.hofmann@griffith.edu.au

Słowa kluczowe: robaki, oddziaływania pasożyt-gospodarz, białka nabłonka powłokowego

\section{STRESZCZENIE}

Pomimo ogromnej skali występowania chorób powodowanych przez nicienie pasożytnicze i inne patogeny wywołujące choroby zakaźne, konieczność poznania molekularnych podstaw wielu tych jednostek chorobowych była przez długi czas niesłusznie lekceważona. Z tego względu kluczowe jest przyspieszenie opracowywania nowych terapii i, w rezultacie, skutecznej kontroli wymienionych chorób. Dzięki obszernym danym uzyskiwanym podczas badań proteomicznych i genomowych możliwe jest identyfikowanie nowych białek biorących udział w oddziaływaniach patogen-gospodarz i na ich postawie badanie molekularnych podstaw tych oddziaływań. Połączenie metod z zakresu biologii systemowej i strukturalnej umożliwia z kolei zastosowanie tej wiedzy do opracowywania skutecznych leków i/lub szczepionek. W tym krótkim artykule przeglądowym opisano dwa różne białka obecne w ścianie ciała przywry krwi: aneksyny i indukowaną przez stres fosfoproteinę 1, które są obecnie uznawane za obiecujące cele terapeutyczne. 